\title{
Apoplastic Invertase and Its Enhanced Expression and Post-translation Control during Fruit Maturation and Ripening
}

\author{
Lili Zhou and Ching-Cheng Chen \\ Departments of Tropical Plant and Soil Sciences, College of Tropical Agriculture and Human Resources, \\ University of Hawaii at Manoa, 3190 Maile Way, Honolulu, HI 96822-2279
}

Ray Ming

Hawaii Agriculture Research Center, 99-193 Aiea Heights Drive, Aiea, HI 96701-3911

David A. Christopher

Molecular Biosciences and Biosystem Engineering, College of Tropical Agriculture and Human Resources, University of Hawaii at Manoa, 3190 Maile Way, Honolulu, HI 96822-2279

\author{
Robert E. Paull ${ }^{1}$ \\ Departments of Tropical Plant and Soil Sciences, College of Tropical Agriculture and Human Resources, \\ University of Hawaii at Manoa, 3190 Maile Way, Honolulu, HI 96822-2279
}

AdDitional INDEX wORDs. Carica papaya, phloem unloading, fruit sugar uptake, sucrose synthetase, fruit development

\begin{abstract}
An invertase gene was isolated and its mRNA activity and protein levels were determined during papaya (Carica papaya L.) fruit development. A complete invertase cDNA (AF420223) and a partial sucrose synthase cDNA (AF420224) were isolated from papaya fruit cDNA libraries. The invertase cDNA encoded a predicted polypeptide of 582 residues (MW 65,537 Da), and was $68 \%$ and $45 \%$ identical with carrot apoplastic and vacuolar invertases, respectively. Key amino acids indicative of an apoplastic invertase were conserved. A full-length gene corresponding to the putative apoplastic invertase cDNA was isolated and was organized into seven exons and six introns. Exon 2 (9 bp long) encoded part of a highly conserved region (NDPNG/A). Invertase mRNA and activity levels increased during fruit maturation and sugar accumulation just before ripening. In contrast, sucrose synthase mRNA levels were high during early fruit growth and low during the fruit sugar accumulation stage. A 73-kDa cell wall extractable protein that cross-reacted with carrot apoplastic invertase antisera substantially increased during papaya fruit maturation and declined in full ripe fruit. The increase in invertase protein levels occurred 2 to 4 weeks before maturity and was markedly higher than the overall increase in enzyme activity at this stage. Subsequently, the increase in enzyme activity was higher than the increase in protein levels between 2 weeks before maturity and fully ripe. The results suggested that mRNA level and invertase activity were related to maturity. The data suggested that the invertase was apoplastic, and that post-translational control of enzyme activity occurred, in which a significant accumulation of invertase occurred before the peak of enzymes activity.
\end{abstract}

Papaya (Carica papaya) sweetness is a major quality factor with a minimum $11.5 \%$ soluble solids being required for Hawaii's fruit (Paull et al., 1997). Sugar accumulation occurs during the last phase of fruit development (Chan et al., 1979; Selvaraj et al., 1982). The activity of a NaCl-soluble acid invertase (Zhou and Paull, 2001) parallels sugar accumulation during the last phase of fruit maturation while sucrose synthase (SS) activity is associated with early fruit growth. Fruit removal and defoliation altered both sugar level and invertase activity in papaya fruit (Zhou et al., 2000), suggesting that invertase was involved in phloem unloading during sugar accumulation.

Invertases enable the transport of sucrose into the apoplast and vacuole by plasma membrane and tonoplast hexose transporters. Numerous forms of invertases ( $\beta$-fructosidase; EC 3.2.1.26) are characterized by solubility, $\mathrm{pH}$ optima, iso-electric points, and

Received for publication: 28 Oct. 2002. Accepted for publication 5 Mar. 2003. University of Hawaii at Manoa, College of Tropical Agriculture and Human Resources journal series 4649. The research represents part of a dissertation submitted by the senior author for the PhD in horticulture. We thank Dr. Sturm for kindly provide carrot invertase antisera, and Gail Uruu and Nancy Chen for technical assistance. This research was funded by USDA-CSREES Grants 9634135-2842 and 98-34135-6458.

1To whom reprint requests should be addressed; e-mail paull@hawaii.edu. subcellular localization (Sturm and Chrispeels, 1990; Sturm 1999). Soluble invertases are intracellular, in either the vacuole (acid optima) or cytosol (neutral or alkaline) (Fahrendorf and Beck, 1990; Karuppiah et al., 1989; Nguyen-Quoc and Foyer, 2001). Soluble acid invertase levels affect the sugar composition of mature fruit tissues (Ho, 1996; Hubbard et al., 1989, 1991; Husain et al., 2001; Klann et al., 1993) and modulate sink strength (Arai et al., 1992; Klann et al., 1996; Ma et al., 2000; Sturm, 1999). Sucrose accumulation in developing tomato fruit is associated with low levels of soluble acid invertase (Klann et al., 1993) and controlled primarily by a recessive acid invertase gene (Egashira et al., 1999). Insoluble (apoplastic, cell wall) invertase increases sugar unloading by maintaining a sucrose concentration gradient between source and sink (Godt and Roitsch, 1997).

Transgenic plants with altered cell wall or vacuolar invertases had different developmental and sugar partitioning patterns (Klann et al., 1996; Ma et al., 2000; Neubohn et al., 2000; Sonnewald et al., 1997; Tang et al., 1999), suggesting that different invertase isoforms may have unique functions. In tomatoes, these invertases are encoded by a small gene family regulated by environmental and metabolic signals (Godt and Roitsch, 1997). The mechanism of phloem unloading varies during tomato fruit growth. During 
early growth, sucrose is unloading symplastically from the phloem without hydrolysis (N'tchobo et al., 1999) though invertases are present. Later in tomato development, sucrose is unloaded apoplastically, involving invertase (Ruan and Patrick, 1995).

A combined molecular and biochemical approach was used to investigate the relationship between the expression of invertase genes and the protein levels and activities of invertase during papaya fruit development. The data presented supports the proposal that the enhanced expression and activity of a cell wall invertase was involved in the accumulation of sugars during the latter stage of fruit development, whereas sucrose synthase was possibly involved in early fruit growth. The results also support post translation control of invertase activity. An understanding of sugar accumulation in papaya would provide alternative approaches to increasing fruit sweetness.

\section{Materials and Methods}

Plant Tissue. 'Sunset' papaya fruit, grown at the University of Hawaii's Poamoho Experimental Station, were used as experimental material. Fruit developmental stages and maturity were estimated by days after anthesis (DAA) and skin, flesh and seed colors as previously described (Zhou et al., 2000). After harvesting, equatorial mesocarp from at least three fruit at each stage was sampled and immediately frozen in liquid nitrogen and stored at $-70^{\circ} \mathrm{C}$ until used.

RNA ISOLATION. Total RNA was isolated according to LopezGomez and Gomez-Lim (1992) as modified by Ikoma et al. (1995). Twenty grams of tissue were ground to a powder with a mortar and pestle in liquid nitrogen, then transferred to a 250-mL centrifuge bottle and vortexed with $40 \mathrm{~mL}$ of lysis buffer [2\% (w/v) SDS, $1 \%(\mathrm{v} / \mathrm{v}) \beta$-mercaptoethanol, $50 \mathrm{~mm}$ EDTA, $150 \mathrm{~mm}$ Tris baseboric acid $(\mathrm{pH} 7.5)]$ plus $60 \mathrm{~mL}$ of water-saturated phenol $(\mathrm{pH}$ 6.5). Chloroform ( $60 \mathrm{~mL})$ was then added and mixed well, and the solution centrifuged $\left(4,000 \mathrm{~g}_{\mathrm{n}}, 10 \mathrm{~min}\right)$ at room temperature. After centrifugation, the aqueous phase was extracted with an equal volume of water-saturated phenol and chloroform, and handled as described by Ikoma et al. (1995). The total RNA was dissolved in $\mathrm{H}_{2} \mathrm{O}$ and quantified. RNA quality was analyzed by electrophoresis on $5 \%$ formaldehyde $/ 1.0 \%$ agarose gel. The total RNA was directly used for RT-PCR, Northern blots, and poly (A)+ mRNA isolation for cDNA library construction.

REVERSE TRANSCRIPTASE PCR (RT-PCR). First strand cDNA was synthesized from total RNA (5 $\mu \mathrm{g})$ using Oligo-dT or random hexamer primers using the Superscript Preamplification System (Bibco-BRL/Life Technologies, Bethesda, Md.). Primer I: 5'GGAATTCAARAAYTGGATGAAYGAYCC-3' (upstream) and primer II: 5'-GCTCTAGAAARTCIRSRCAYTCCCACATICC-3' (downstream, I = inosine), were from highly conserved regions of known cell wall and vacuolar invertase genes (Davies and Robinson, 1996; Hedley et al., 1994; Mercier and Gogarten, 1995; Sturm and Chrispeels, 1990). Primer III: 5'-GCTCTAGAGGDATIMDYTGIAYICYIGCC-3' (downstream), was a conserved region in cell wall invertase genes (Hedley et al., 1994; Mercier and Gogarten, 1995; Sturm and Chrispeels, 1990). The PCR consisted of $2 \mu \mathrm{L}$ of the first strand cDNA, $1 \times$ PCR buffer (Promega, Madison, Wis.), $1.5 \mathrm{~mm} \mathrm{MgCl}, 0.2 \mathrm{~mm}$ dNTP, $100 \mathrm{ng}$ each upstream (forward) and downstream (reverse) primer, and 2 units of Taq DNA polymerase (Promega) in a $50 \mu \mathrm{L}$ reaction volume. The thermocycling regime was: $94{ }^{\circ} \mathrm{C}$ for $6 \mathrm{~min}$, followed by 40 cycles of $94^{\circ} \mathrm{C}$ for $1 \mathrm{~min}$, $42{ }^{\circ} \mathrm{C}$ for $1 \mathrm{~min}, 72^{\circ} \mathrm{C}$ for $1.5 \mathrm{~min}$. The final extension period was $72{ }^{\circ} \mathrm{C}$ for $7 \mathrm{~min}$. PCR products were analyzed on a $1 \%$ agarose
(1× TAE) (40 mm Tris-HCl, $\mathrm{pH} 7.4,20 \mathrm{~mm}$ sodium acetate, $1 \mathrm{~mm}$ EDTA) gel.

CONSTRUCTION AND SCREENING OF CDNA LIBRARY. Total RNA was isolated from $250 \mathrm{~g}$ of fruit flesh $\approx 2$ weeks before harvest as described above. Poly (A)+ mRNA was isolated using the poly (A) + Tract mRNA isolation system (Promega). Poly (A) + mRNA $(10 \mu \mathrm{g})$ was used to synthesize the cDNA, ligated into a $\lambda$ Zap vector (Stratagene, La Jolla, Calif.). PCR was performed using invertase forward and reverse primers at each stage of cDNA library construction to determine the presence of invertase cDNA. The primary library was amplified, stored at $4{ }^{\circ} \mathrm{C}$ in $7 \%(\mathrm{v} / \mathrm{v})$ DMSO at $-70^{\circ} \mathrm{C}$.

About $1.2 \times 10^{6}$ phages were screened by plaque-hybridization on Magna nylon membranes (Micron Separation Inc., Westboro, Mass.) using the cloned RT-PCR products (558 and $889 \mathrm{bp}$ ) as probes $\left(1 \times 10^{-9} \mathrm{cpm} / \mu \mathrm{g}\right)$ (Sambrook et al., 1989). The resulting positive plaques were analyzed by PCR using invertase specific primers. Positive plaques producing the correct size PCR product were converted to pBluescript SK (-) phagemids according to the manufacturer's instructions (Stratagene, La Jolla, Calif.).

Cloning OF The InVERTASE AND SS cDNA Fragment. The 558-bp and 889-bp fragments obtained from PCR were unidirectionally cloned into the EcoR I/Xba I sites of the pGEM $7 \mathrm{Z}$ and pBluescript-SK (-) vectors, respectively, and maintained in Escherichia coli XL1-Blue. DNA sequencing was used to confirm that the PCR products had homology to cell wall invertase.

The SS gene fragment was obtained by PCR using a cDNA library made from immature green fruit (described above) as template and primers designed to conserved regions found within various plant SS. The forward primer, 5'-CCTGAC/ TACC(T)GGTGGA(C/T)C-AG-GT-3' and reverse primer, 5'TCA(G)GA(T)GTAA(T)GGA(G)AAA(G)TAA(G/T)A-3' gave two PCR products ( 1000 and $720 \mathrm{bp}$ ) as detected on a $1 \%$ agarose TAE gel. The 720-bp product was close to the anticipated size based on the protein sequence. Direct sequencing of the two purified bands confirmed that the second band was homologous to known SS gene sequences. Fresh PCR product was cloned into the SK (-) phagemid EcoR V site using the $\mathrm{T}$ tail cloning technique (Marchuk et al., 1991). DNA sequence analysis was used to confirm the correct recombinants.

RNA ANALYSIS. Total RNAs extracted from young and mature leaves, flowers, young stems, mature leaf petioles, 6 month old seedling roots, immature seeds, young fruit flesh (14 DAA), and fruit flesh from five later stages of development were used for Northern analysis. Northerns were prepared from total RNA (10 $\mu \mathrm{g}$ ) fractionated on $1 \%$ agarose-5\% formaldehyde gels. Gene specific antisense RNA probes were synthesized and radiolabeled with $\left[\alpha-{ }^{32} \mathrm{P}\right]$ UTP $(>3000 \mathrm{Ci} / \mathrm{mm}$, ICN Pharmaceuticals, Inc., Costa Mesa, Calif.) using T3 RNA polymerase and $1 \mu \mathrm{g}$ of linearized plasmid DNA according to the enzyme manufacturer (Promega). The blots were hybridized with $2.5 \times 10^{6} \mathrm{cpm}$ of probes at $55^{\circ} \mathrm{C}$ in buffer containing $0.75 \mathrm{M} \mathrm{NaCl}, 75 \mathrm{~mm}$ sodium citrate, $50 \%$ (v/v) formamide, $2 \times$ Denhardt's solution, $25 \mathrm{~mm}$ monobasic sodium phosphate, $25 \mathrm{~mm}$ dibasic sodium phosphate, $1.5 \%(\mathrm{w} / \mathrm{v}) \mathrm{SDS}$, and $5 \mu \mathrm{g} \cdot \mathrm{mL}^{-1}$ salmon sperm DNA and visualized by autoradiography.

GenOMic DNA ISOlation AND Southern ANALYSIS. Genomic DNA was isolated from leaves (Doyle and Doyle, 1987) and $\approx 10 \mu \mathrm{g}$ of DNA was digested with EcoRV, HindIII, and XbaI (Promega), then fractionated on a $0.8 \%(\mathrm{w} / \mathrm{v})$ agarose TAE gel. Prehybridization and hybridization were performed as for the Northerns, except the hybridization temperature was $45^{\circ} \mathrm{C}$. 
ANALYSIS OF INVERTASE CLONES. T3 and T7 primers were used for preliminary DNA sequence analysis of the positive clones. A clone was confirmed to encode cell wall invertase by comparison with published invertase sequences. All sequencing was performed using an automated ABI Prism 373 DNA sequencer. The cDNA sequence (AF420223) data from each DNA fragment was compiled into a whole length sequence and mapped using the GCG program (Genetic Computer Group, Madison, Wis.).

BAC library construction and isolation of invertase gene. High molecular weight DNA was isolated from young papaya leaves (Zhang et al., 1995). The BAC vector, pBeloBAC11 (Shizuya et al., 1992) was isolated by alkaline lysis (Sambrook et al., 1989) and twice purified on cesium chloride density gradient centrifugation. The vector was completely digested with Hind III and dephosphorylated by shrimp alkaline phosphatase (Amersham Pharmacia Biotech, Piscataway, N.J.). Partially digested and size-selected Hind III DNA fragments were ligated into the dephosphorylated vector. Three samples of the ligation mix were used to transform $25 \mu \mathrm{L}$ of $E$. coli ElectroMAX DH10B cells by electroporation. After electroporation, the cells were resuspended in SOC medium and incubated at $37^{\circ} \mathrm{C}$ for $45 \mathrm{~min}$ while shaking at $200 \mathrm{rpm}$. The cells were then plated on LB medium containing chloramphenicol, X-GAL and IPTG, and grown at $37{ }^{\circ} \mathrm{C}$ for 35 to $48 \mathrm{~h}$. White (recombinant) colonies were innoculated into 96-well plates containing $150 \mathrm{~L}$ of $\mathrm{LB}$ freezing media at $37^{\circ} \mathrm{C}$ overnight. Clones were randomly chosen from each transformation to determine the insert sizes. Not I digested clones were separated by pulse field gel electrophoresis (PFGE) on a $1 \%$ agarose gel. The insert size of each clone was determined by the sum of the sizes of all bands compared with a lambda midrange size standard (New England Biolabs, Beverly, Mass.), excluding the cloning vector band. This BAC library consisted of 39,168 clones from two separate ligation reactions. The average insert size of the whole library was $132 \mathrm{~kb}$.

High-density filters were made by replicating 48,384-well microtiter plates onto a single $22.5 \times 22.5-\mathrm{cm}$ nitrocellulose (Hybond NT) filter using Q-BOT (Genetix, U.K). Clones were double spotted using a $4 \times 4$ array with six fields per filter. The grid pattern allowed 18,432 clones to be spotted on one filter. Colony filters were processed and hybridized using standard techniques (Sambrook et al., 1989). Probes derived from the cloned papaya fruit invertase cDNA were hybridized to two high-density filters to identify BAC clones containing this gene. A positive clone with an insert $\approx 100 \mathrm{~kb}$, without subcloning, was sequenced.

INVERTASE ENZYME EXTRACTION AND ASSAY. Invertase was eXtracted from the fruit mesocarp in the absence and presence of $1 \mathrm{M} \mathrm{NaCl}$ to enhance the extraction of cell wall bound invertase (Fahrendorf and Beck, 1990). The extraction buffer contained 100 mм MOPS-NaOH (pH 7.5), 5 mм $\mathrm{MgCl}_{2}, 1$ mм EDTA, $2.5 \mathrm{~mm}$ DTT, $0.5 \mathrm{mg} \cdot \mathrm{mL}^{-1} \mathrm{BSA}, 2 \%$ (v/v) glycerol, $1 \mathrm{~mm} \mathrm{PMSF}, 0.05 \%$ (v/v) Triton X-100, and the desalting buffer contained $50 \mathrm{~mm}$ MOPS-NaOH (pH 7.5), $5 \mathrm{~mm} \mathrm{MgCl}_{2}, 0.5 \mathrm{mg} \cdot \mathrm{mL}^{-1} \mathrm{BSA}, 2.5 \mathrm{~mm}$ DTT, 1 mм PMSF. Invertase activity was assayed as previously described (Zhou and Paull, 2001).

For gel electrophoresis and immunoblot analysis, fruit mesocarp tissue was sequentially extracted. The fruit mesocarp was ground, and allowed to stand for $30 \mathrm{~min}$ on ice in extraction buffer minus BSA, plus $1 \mathrm{~mm}$ dithiodipyridine and $10 \mu \mathrm{m}$ (E-64 then filtered through) Miracloth. BSA was omitted from the extraction buffer to enable protein quantification (Lowry et al., 1951), and the 1 mm dithiodipyridine and $10 \mu \mathrm{M}$ E-64 were added to inhibit papain activity. The filtrate pellet was washed twice with extraction buffer and pooled with the original supernatant. The washed pellet was then extracted again with extraction buffer plus $1 \mathrm{~m} \mathrm{NaCl}$ and shaken for $1 \mathrm{~h}$ on ice before centrifugation $\left(10,000 \mathrm{~g}_{\mathrm{n}}, 30 \mathrm{~min}\right)$. The $1 \mathrm{~m} \mathrm{NaCl}$ extracted supernatant was desalted as above.

Protein gel electrophoresis and immunoblotting. Total proteins were separated by SDS-PAGE on $12.5 \%$ gels and either stained with Coomassie blue or electrophoretically transferred onto $0.45 \mu \mathrm{m}$ nitrocellulose membranes for immuno-blot analysis. Rabbit polyclonal antisera for carrot cell wall invertase and carrot soluble invertase, kind gifts of Dr. Strum (Lauriare et al., 1988; Unger et al., 1992), were used. Cross reactive polypeptides were visualized with goat antirabbit IgG secondary antibody conjugated to alkaline phosphatase. Immunodetection was performed following the instruction of ECL Western Blotting System (Amersham Pharmacia Biotech Inc., Piscataway, N.J.).

\section{Results}

Cloning of An invertase cDNA From green PAPAya Fruit. Two RT-PCR products that had the anticipated size (558 bp and $889 \mathrm{bp}$ ) were obtained by using the same forward primer and two different reverse primers. The two products had identical nucleotide sequences in the overlapping region. The purified 558 and 889 bp cDNAs were cloned and used as probes to screen a cDNA library. A cDNA was reproducibly isolated from multiple rounds of library screening. The complete amino acid sequence was deduced from the cDNAs (Fig. 1). The sequence had an open reading frame that encoded a polypeptide chain of 582 residues, calculated MW of 65,537 Da, and an isoelectric point of 6.61. The predicted papaya invertase polypeptide was $68 \%, 66 \%, 64 \%$ and $63 \%$ identical to carrot1 P26792 (Sturm and Chrispeels, 1990), carrot 3X79423 (Lorenz et al., 1995), potato Z22645 (Hedley et al., 1994), and Arabidopsis U11033 (Mercier and Gogarten, 1995) cell wall invertases, respectively, and $45 \%$ identical to soluble invertases from tomato (Elliot et al., 1993), potato (Zhou et al., 1994), and carrot (Unger et al., 1994).

ISOLATION OF PAPAYA PUTATIVE CELL WALL INVERTASE GENE. The coding region of the papaya putative cell wall invertase gene isolated was organized into seven exons and six introns (Fig. 2). The intron sequences were deduced by comparison with protein-coding sequence of the cloned cDNA. All six introns had the boundary sequences 5'-GT/AG-3' at the splicing sites. Exon 2 was only 9 nt long and encoded part of a highly conserved region (NDPNG/A).

Cloning of SS cDNA fragment. A 720-bp PCR product (AF420224) was obtained by RT-PCR using primers complementary to conserved SS sequences. The nt sequence of the 720 bp PCR product was highly homologous to Arabidopsis glutinosa mRNA (X92378, 82\% identical), Vicia faba mRNA (X69773, $81 \%$ identical) and SS genes of other species (data now shown). The deduced amino acid sequence was $\approx 85 \%$ to $90 \%$ identical to all sequences in the alignment.

SOUTHERN ANALYSIS. Restriction digested DNA from papaya leaves hybridized with gene specific antisense riboprobes for invertase to one or two restriction fragments (Fig. 3). This suggests that the invertase was present as a single gene copy number.

RNA analysis of invertase and SS mRNA levels in different papaya tissue and during fruit development. RNA analysis using invertase-specific probes were done on samples from different stages of fruit development and papaya plant tissues (Fig. 4). Invertase mRNA abundance increased with fruit development and reached a maximum at the mature fruit stage ( $30 \%$ yellow), and 


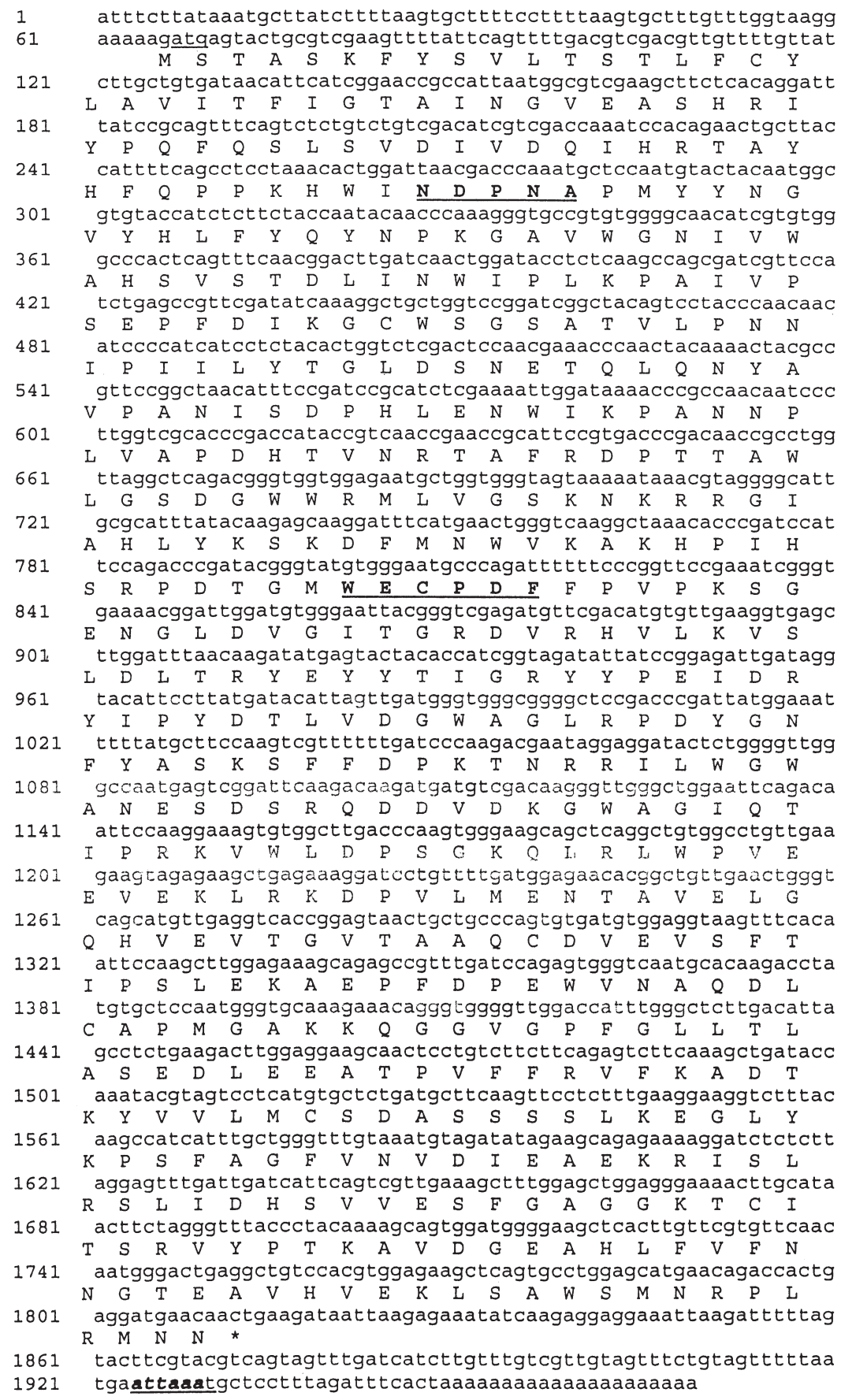

Fig. 1. Nucleotide and deduced amino acid sequences showed beneath the nucleotide sequence of the sense strand of the papaya invertase cDNA isolated from green papaya fruit ( 2 weeks before maturity). The conserved amino acid sequences used to make degenerate PCR primers were boldface and underlined. The putative poly $(\mathrm{A})^{+}$signal sequence is presented in italics and underlined (attaaa, 1924 to 1929).

then decreased in full ripe fruit. Significant, but lower levels of invertase mRNA were also detected in leaves and flowers, while minimal levels were detected in petioles, roots and seeds (Fig. 4). In contrast, SS mRNA abundance was highest in petioles and very young fruit (14 DAA) and was detected at a minimal level in developing and ripening fruit (Fig. 4).

INVERTASE PROTEIN LEVELS DURING PAPAYA FRUIT DEVELOPMENT. Hybridization of protein blots with the antibody to carrot cell wall acid invertase showed a significant increase in the levels of extracted cell wall invertase proteins during papaya fruit development and ripening (Fig. 5). The carrot polyclonal cell wall invertase antisera detected a strong signal at $\approx 73 \mathrm{kDa}$ in proteins extracted without $1 \mathrm{M} \mathrm{NaCl}, 2$ weeks before the fruit began to ripen and at the full ripe stage (Fig 5. lane 2 and lane 5). Two weaker bands at $\approx 63$ and $53 \mathrm{kDa}$ were also detected, which might be minor invertase isoforms or degraded products. When the washed filtrate pellet was extracted again in the presence of $1 \mathrm{~m} \mathrm{NaCl}$, the same molecular weight bands were detected that peaked 2 weeks before harvest (lane 4). The $73-\mathrm{kDa}$ and $53-\mathrm{kDa}$ bands on pellet from 2 weeks before harvest and extracts from full ripe fruit with $\mathrm{NaCl}$ were low compared to the supernatant from 2 weeks before harvest and full ripe fruit without $\mathrm{NaCl}$, respectively. This was possibly due to the proportion of invertase protein being reduced relative to the other proteins that became soluble in the presence of $1 \mathrm{M} \mathrm{NaCl}$.

The carrot soluble invertase $43 \mathrm{kDa}$ and 25 $\mathrm{kDa}$ subunits only cross-reacted with papaya invertase when the hybridization was carried out at $30{ }^{\circ} \mathrm{C}$. The signal detected by soluble invertase antisera was much weaker than for carrot cell wall invertase antisera in the same blot and hybridization conditions (data not shown).

INVERTASE ACTIVITY DURING PAPAYA FRUIT DEVELOPMENT. Buffer soluble $(-\mathrm{NaCl})$ and total $(+\mathrm{NaCl})$ invertase activities were both low 10 weeks before fruit maturity and increased 6 weeks before fruit maturity (Fig. 6). Buffer soluble invertase activity increased 2 to 4 weeks before ripening, decreased slightly then substantially increased again during ripening. The total invertase activity $(+\mathrm{NaCl})$ increased steadily from the pre-maturation to full ripe stage and was 4.7 -fold higher than buffer soluble invertase activity 4 weeks before maturity and 18-fold higher in mature fruit at the color break stage. Soluble invertase activity was $94 \%$ of the total invertase activity when fruit were fully ripe, as soluble invertase activity increased 26 -fold while total activity increased only 1.5 -fold during the $7 \mathrm{~d}$ postharvest period.

\section{Discussion}

Multiple invertase genes have been found in tomato (Klann et al., 1993; Godt and Roitsch 1997), potato (Hedley et al., 1994; Zhou et al., 1994), carrot (Sturm, 1996), grape (Davies and Robinson, 1996) and maize (Carlson and Chourey, 1999; Kim et al.,

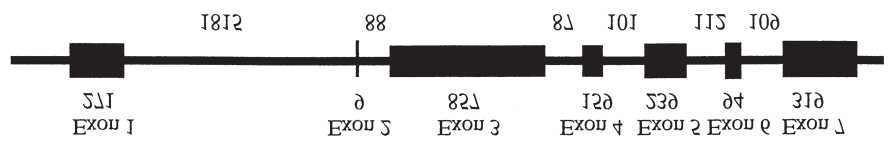

Fig. 2. The structure of the isolated papaya fruit cell wall invertase gene, exons and introns are presented by shaded boxes and lines, respectively. 


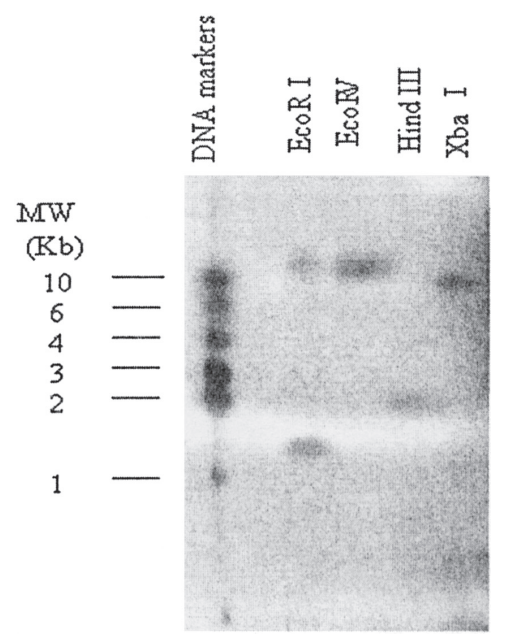

Fig. 3. Southern analysis of papaya cell wall invertase gene, genomic DNA $(10 \mu \mathrm{g})$ from 'Sunset' papaya leaves was digested with either EcoR I, EcoR V, Hind III, or Xba $\mathrm{I}$, and hybridized with the gene specific probes for papaya cell wall invertase.

2000). Cell wall invertase and vacuolar invertase show spatial and temporal expression patterns related to their distinct functions during growth and maturation. This study provides evidence that the expression of a papaya fruit invertase gene was differentially enhanced during late fruit maturation and may be post-translationally regulated. The predicted polypeptides from the isolated cDNA had high sequence identity (63\% to $68 \%)$ to cell wall invertases and lower identity (45\%) to vacuolar and soluble invertase isoforms (Klann et al., 1993; Tang et al., 1999). No vacuolar invertase mRNA was detected in immature green and full ripe papaya fruit via RT-PCR and screening of cDNA library.

The amino acid sequence predicted from the isolated cDNA (Fig. 1) had two highly conserved functional domains representative of cell wall invertases. These included the substitution of Ile (apoplastic) for Met (vacuolar) in N-terminal domain A, and Pro (apoplastic) for Val (vacuolar) in domain B, respectively. Domain Acontains the $\beta$-fructosidase motif, while domain $B$ contained the conserved Cys believed to be involved in the catalytic function of invertases (Sturm and Chrispeels, 1990; Hedley et al., 1994). In addition, a variable leader sequence and high isoelectric point are proposed to be characteristic of extracellular invertases (Roitsch et al., 1995). High pI is thought to be a typical biochemical property of cell wall invertase that is essential for cell wall binding. The papaya invertase had a putative 53 amino acid leader in a nonconserved amino terminus. It also had a calculated pI of 6.61, which is lower than most known extracellular invertases, but 0.47 to 1.16 higher than vacuolar invertases (Davies and Robinson, 1996). Other apoplastic invertases that have intermediate isoelectric points occur in Chenopodium rubrum of 6.2 (Ehness and Roitsch, 1997) and 7.0 (INCW1) and 5.5 (INCW4) from maize (Kim et al., 2000). Kim et al., (2000) suggested that the low pI cell wall invertase isolated from maize may represent a new type of cell wall invertase present in a free form in the apoplast. The exon genomic sequence (Fig. 2) was identical to the cell wall invertase cDNA sequence.

The identity of an apoplastic invertase from papaya fruit was supported immunologically and biochemically by the finding that the antisera raised against the carrot cell wall invertase reacted more strongly with a protein in papaya fruit than did the antisera made against the soluble invertase (Fig 5). Polyclonal antisera against the apoplastic isoform of carrot invertase detected proteins of $\approx 73$ and $53 \mathrm{kDa}$. The predicted $\mathrm{MW}$ of the polypeptide from the papaya invertase cDNA was $65,537 \mathrm{Da}$, close to the estimated MW of $73 \mathrm{kDa}$ from denaturing gels, the difference possibly due to glycosylation. The molecular mass of invertase has been reported as $275 \mathrm{kDa}$ for the soluble invertase from full ripe papaya fruit (Chan and Kwok, 1976), which would be a tetramer having subunits of $68.75 \mathrm{kDa}$ as encoded by the cDNA.
Fig. 4. Northern analysis of cell wall invertase (panels 1 and 2) and sucrose synthetase (panel 3) gene expression in different plant tissues and fruit developmental stages. Gene specificprobes forinvertase and sucrose synthetase were used. Total RNAs were extracted from different tissues and stages of fruit development $(\mathrm{Y} 2=6$ weeks before maturity; $\mathrm{Y} 3=\approx 4$ weeks beforematurity; $2 \mathrm{WB}=2$ weeks before maturity; mature, (color break to $30 \%$ yellow) and full ripe. Panel $2=$ longer 3 exposure of blots in panel 1 .

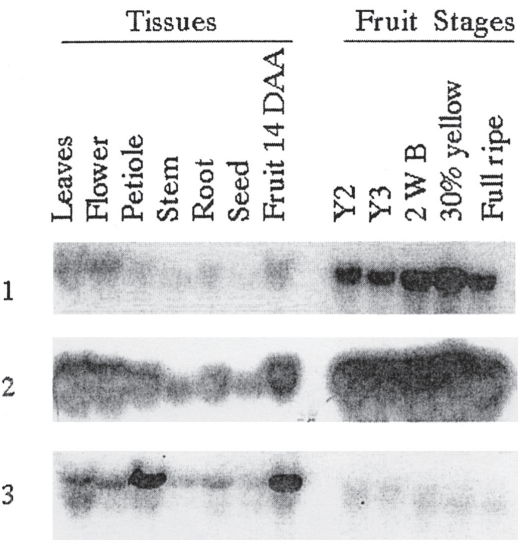

The $52 \mathrm{kDa}$ for a mature green papaya fruit invertase extracted using a buffer saturated ammonium sulphate (Lopez et al., 1988) was close to the $53-\mathrm{kDa}$ band detected by carrot cell wall invertase and soluble invertase antisera. The molecular masses of the two forms of heterologous invertases from yeast were 81.5 and $78.3 \mathrm{kDa}$ in denatured gel, and 221 and $200 \mathrm{kDa}$ in nondenaturing PAGE (Pérez et al., 2001). The folded glycosylated peptide could have effectively shielded the protein from antibody binding and increased its mobility in the gel (Weil et al., 1994). Thus, the unique $\approx 30 \mathrm{kDa}$ protein detected by the antisera (data not shown) could be a subunit of invertase, a breakdown product, or an incompletely denatured protein. Overall, the sizes of the papaya subunits under denaturing conditions were in agreement with the previously reported invertase subunits, from a variety of plant species of 30,38, 58,63,64, and $68 \mathrm{kDa}$ (Arai et al., 1992; Bracho and Whitaker 1990; Iwatsubo et al., 1992; Unger et al., 1992; Yelle et al., 1991).

The accumulation of presumed apoplastic invertase protein paralleled an increase in cell wall invertase activity during fruit ripening (Fig. 6). No difference in protein size was detected by the antisera of protein extracted with and without $1 \mathrm{M} \mathrm{NaCl}$ in the

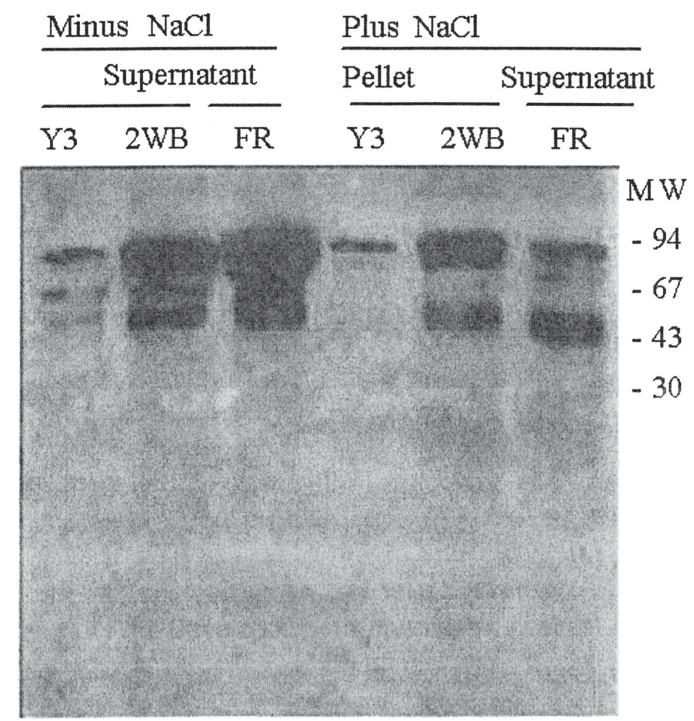

Fig. 5. Immunoblot analysis of extracted invertase protein levels during papaya fruit development, $50 \mu \mathrm{g}$ protein was loaded per lane. Mesocarp tissue (Y3 and 2WB) was first extracted without $\mathrm{NaCl}$ in the extraction buffer $(-\mathrm{NaCl})$, the pellet from this extraction was then extracted again with buffer plus $1 \mathrm{M} \mathrm{NaCl}$ to remove cell wall bound invertase. Mesocarp from full ripe fruit (FR) was extracted either with or without $\mathrm{NaCl}$ in the extraction buffer and the supernatant used. Antisera for the carrot cell wall invertase was used. Y3 $=4$ weeks before maturity; $2 \mathrm{WB}=2$ weeks before maturity. FR = full ripe. 


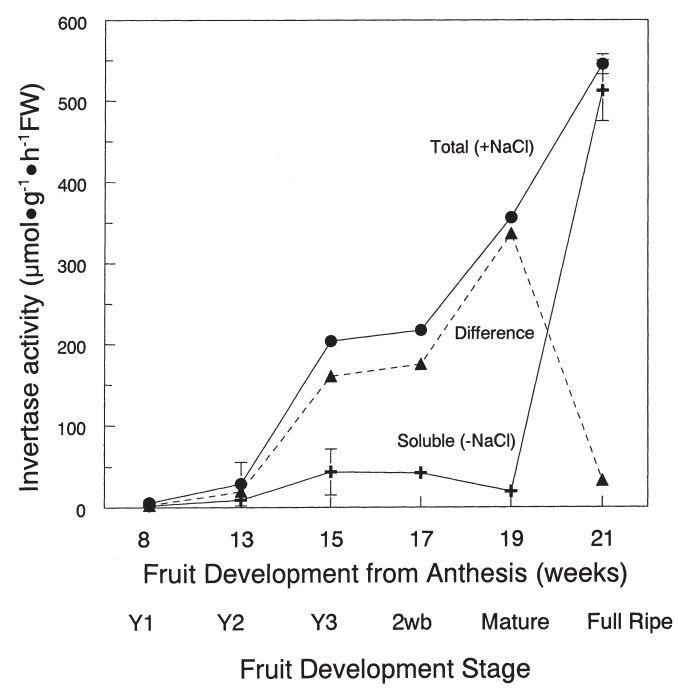

Fig. 6. Invertase activities $\left(\mu \mathrm{mol} \cdot \mathrm{h}^{-1} \cdot \mathrm{g}^{-1}\right.$ fresh weight, $\left.\mathrm{pH} 5.0,22{ }^{\circ} \mathrm{C}\right)$ during papaya fruit development. Protein was extracted in the presence $[+\mathrm{NaCl}$, total invertase (buffer soluble and salt extracted)] and the absence $(-\mathrm{NaCl}$, buffer soluble invertase) of $1 \mu \mathrm{M} \mathrm{NaCl}$ from fruit flesh at different developmental stages $(\mathrm{Y} 1=$ fruit younger than 10 weeks, $\mathrm{Y} 2=\approx 6$ weeks before maturity, $\mathrm{Y} 3=\approx 4$ weeks before maturity, $2 \mathrm{WB}=2$ weeks before maturity, mature = color break to $30 \%$ yellow (harvest maturity), full ripe $=$ skin fully yellow $(7$ $\mathrm{d}$ after harvest). The difference between total minus buffer soluble invertase activity was also plotted. Each data point represents the average of at least two individual fruit extractions, three measurements were done on each extraction. Vertical bars indicate SD.

extraction buffer. The absence of MW differences suggested that the proteins detected were the same invertase isoforms. Moreover, the level and distribution of cell wall-bound invertase activity (Fig. 6) was associated with the differential accumulation of mRNA detected using the papaya invertase cDNA probe (Fig. 4). The data taken together supported the proposal that a papaya fruit cell wall invertase gene was expressed during late fruit maturation. During this stage, sucrose accumulates from 4 to $38 \mathrm{~g} \cdot \mathrm{kg}^{-1}$ (fresh weight) in the mesocarp and is $\approx 50 \%$ of the total sugars (Zhou and Paull, 2001).

The increased invertase protein level in the minus $\mathrm{NaCl}$ extraction during fruit ripening (Fig. 5) was possibly associated with cross reaction with soluble invertase and some cell wall invertase that was also extracted. When the pellet was reextracted with $\mathrm{NaCl}$, a peak in invertase cross reactivity occurred 2 weeks before harvest, this declined in full ripe fruit and the trend paralleled the difference curve between total and $\mathrm{NaCl}$ extracted enzyme activity (Fig. 6). The increase in the levels of the soluble invertase (minus $\mathrm{NaCl}$, Fig. 6) during postharvest ripening may have been due to cell wall degradation (papaya fruit become very soft at this stage), that facilitated the release of apoplastic invertase during extraction, rather than a change in the isoform or subcellular distribution, although the presence of soluble isozyme is not excluded. This is consistent with the observation of Perez et al (2001) who found that $99 \%$ of periplasmic invertase in yeast cells was solubilized during the conversion of cells into protoplasts. The size of the invertase protein released by zymolyase digestion was identical to that of the invertase solubilized during the conversion of the cells into protoplasts (Pérez et al., 2001). Carlson and Chourey (1999) also reported that changes in the enzyme activity are attributable to a cell wall invertase protein in the soluble fraction. Papaya sucrose is lost within 2.6 min following homogenization (Chan and Tang, 1979), unless the tissue is subjected to preheating to denature invertase before extraction.
The solubility of invertase enzymes is affected by the $\mathrm{pH}$ of extraction buffer, extraction method, and $1 \mathrm{M} \mathrm{NaCl}$. The difference in activity between extracts made in the presence and absence of $\mathrm{NaCl}$ was used to estimate cell wall invertase activity in the current study. Papaya invertase activity was $>15$ times higher when $1 \mathrm{M} \mathrm{NaCl}$ was included in the extraction for mature green fruit (Fig. 6). Preliminary tissue blot experiments showed that invertase proteins were mostly distributed around the vascular tissue of immature green fruit and spread throughout the mesocarp in full ripe soft fruit (data not shown). When fresh fruit juice was incubated at room temperature for $20 \mathrm{~min}$, the reducing sugar levels increased $54 \%$ and $97 \%$ for mature green and full ripe fruit, respectively (unpublished data). This, combined with the much higher invertase activity and sucrose levels in mature papaya fruit (Zhou and Paull, 2001), suggested that the sucrose and invertase were physically separated in vivo. This explanation is consistent with the 26-fold increase in salt soluble invertase activity during ripening. Whole soluble sugar composition is unaffected (Zhou and Paull, 2001).

Busse and Laties (1993) found that ethylene and sugar could regulate invertase gene expression at the transcriptional and posttranscriptional levels. Sugar level can regulate the expression of invertase and SS genes in plants (Isla et al., 1991; Koch, 1996). SS gene expression, was highest in young fruit and decreased as the fruit developed (Fig. 4). SS enzyme activity remained constant (Zhou and Paull, 2001) and SS mRNA decreased to low levels at the ripening stage. SS activity may control sucrose import capacity in young fruit (Koch, 1996) and possibly also in papaya.

A trans-membrane sucrose gradient between the phloem and apoplast of adjacent cells can be maintained or increased by apoplastic invertase cleaving sucrose into glucose and fructose (Sturm and Chrispeels, 1990). A high apoplastic invertase activity in sinks may increase sucrose transport to these organs and thus increase sink strength (Ho, 1984; Morris, 1982). The increase in mRNA level, protein level and invertase activity, during the late stage of papaya fruit development suggested that cell wall invertase may be a major contributor to sugar accumulation during the late phase of fruit maturation before ripening. Protein analysis (Fig. 5) and invertase activity assays (Fig. 6) confirmed that a cell wall invertase was a major form during the late stage of papaya fruit development. This conclusion agrees with the model proposed by Eschrich $(1980,1989)$ for phloem unloading. Our observations are supported by previous experiments in which modification of cell wall or vacuolar invertases using antisense in potato (Heineke et al., 1992; Sonnewald et al., 1997), tomato (Klann et al., 1996), and carrot (Tang et al., 1999) dramatically affected plant development and sugar partitioning in sink tissue. Furthermore, the different expression patterns of invertase and $\mathrm{SS}$ in the sink tissues suggested that, regarding sugar partitioning, SS was a predominant enzyme in young fruit and petioles (D'Aoust et al., 1999), while invertase was more important in the young leaves, flowers and mature fruit.

Papaya showed strict regulation of invertase gene expression and enzyme activity during fruit development. Cell wall invertase activity in papaya may be regulated by the availability of assimilate supply. Papaya fruit removal, which may increase assimilate supply to the remaining fruit, led to an earlier increase in invertase activity (Zhou et al., 2000), while defoliation, that reduced assimilate supply, delayed an invertase activity increase during the late stage of fruit development. Increased invertase mRNA level (Fig. 4), protein level (Fig. 5), invertase enzyme activity (Fig. 6), and sucrose accumulation (Zhou and Paull, 2001) occurred 
during the last stage of fruit development, 4 weeks before maturity and the commencement of ripening. However, there were distinct differences, the increase in $\mathrm{mRNA}$ and invertase protein levels occurred 2 to 4 weeks before maturity and this increase was markedly higher than the overall increase in enzyme activity between these stages. Subsequently, the increase in enzyme activity was higher than the increase in protein levels between 2 weeks before maturity and fully ripe. These observations suggested a post-translational control of enzyme activity and a two-stage mechanism of gene activation in which a significant amount of invertase protein accumulated before the peak of enzymes' activity. Transgenic papaya plants with enhanced cell wall invertase would be expected to have higher sucrose levels. Choice of a mesocarp and specific fruit growth stage gene promoter would reduce disruption of the plant's source-sink balance.

\section{Literature Cited}

Arai M, H. Mori, and H. Imaseki. 1992. Cloning and sequence of cDNAs for an intracellular acid invertase from etiolated hypocotyls of mung bean and expression of the gene during growth of seedlings. Plant Cell Physiol. 33:245-252.

Bracho, G.E. and J.R. Whitaker. 1990. Purification and partial characterization of potato (Solanum tuberosum) invertase and its endogenous proteinaceous inhibitor. Plant Physiol. 93:386-294.

Busse EL, Laties GG (1993) Ethylene-mediated post-transcriptional regulation in ripening avocado (Persea americana) mesocarp discs. Plant Physiol 102:417-423

Carlson, S.J. and P.S. Chourey. 1999. A re-evaluation of the relative roles of two invertases, INCW2 and IVR1, in developing maize kernels and other tissues. Plant Physiol. 121:1025-1035.

Chan, J.R.H.T. and S.C.M. Kwok. 1976. Isolation and characterization of a $\beta$-fructofuranosidase from papaya. J. Food Sci. 41:320-323.

Chan, H.T. and C.S. Tang. 1979. The chemistry and biochemistry of papaya, p. 33-53. In: G.E. Inglett and G. Charalambous (eds.). Tropical foods: Chemistry and nutrition. Academic Press, New York.

Davies, C. and D.P. Robinson. 1996. Sugar accumulation in grape berries: cloning of two putative vacuolar invertase cDNAs and their expression in grapevine tissues. Plant Physiol. 111:275-283.

D'Aoust, M.A., S. Yelle, and B. Nguyen-Quoc. 1999. Antisense inhibition of tomato fruit sucrose synthase decreases fruit setting and sucrose unloading capacity of young fruit. Plant Cell 11:2407-2418.

Doyle, J.J. and J.L. Doyle. 1987. A rapid DNA isolation procedure for small quantities of fresh leaf tissue. Phytochem. Bul. 19:11-15.

Egashira, H., S. Takahashi, H. Doi, T. Nishizawa, A. Escalante, T. Takashina, and S. Imanishi. 1999. Genetic analysis of sucrose-accumulating ability in Lycopersicon peruvianum. Breeding Sci. 49:155-159.

Ehness, R. and T. Roitsch. 1997. Differential effect of D-glucose on the level of mRNAs for three invertase isoenzymes of Chenopodium rubrum. J. Plant Physiol. 150:514-519.

Elliott, K.J., W.O. Butler, C.D. Dickenson, Y. Konno, T.S. Vedvick, L. Fitzmaurice, and T.E. Mirkov. 1993. Isolation and characterization of fruit vacuolar invertase genes from two tomato species and temporal differences in mRNA levels during fruit ripening. Plant Mol. Biol. 21:515-524.

Eschrich W (1980) Free space invertase: its possible role in phloem unloading. Ber. Dtsch Bot Ges 93:363-378

Eschrich W (1989) Phloem unloading of photoassimilates, p. 206-263. In. D.A. Baker and J.A. Milburn (eds.). Translocation of photoassimilates. Longman Scientific and Technical, London

Fahrendorf, T. and E. Beck. 1990. Cytosolic and cell wall bound invertases from leaves of Urtica dioica L.: A comparison. Planta 180:237-244.

Godt, D.E. and T. Roitsch. 1997. Regulation and tissue-specific distribution of mRNAs for three extracellular invertase isoenzymes of tomato suggests an important function in establishing and maintaining sink metabolism. Plant Physiol. 115:273-282.

Hedley, P.E., G.C. Machary, H.V. Davies, L. Burch, and R. Waugh.
1994. Potato (Solanum tuberosum) invertase-encoding cDNAs and their differential expression. Gene 145:211-214.

Heineke, D, U. Sonnewald, D. Bussis, G. Gunter, K. Leidreiter, I. Wilke, K. Raschke, L. Willmitzer, and H.W. Heldt. 1992. Apoplastic expression of yeast derived invertase in potato: Effects on photosynthesis, leaf solute composition, water relations, and tuber composition. Plant Physiol. 100:301-308.

Ho, L.C. 1984. Partitioning of assimilates in fruiting tomato plants. Plant Growth Regulat. 2:277-285.

Ho, L.C. 1996. The mechanism of assimilate partitioning and carbohydrate compartmentation in fruit relation to the quality and yield of tomato. J. Expt. Bot. 47:1239-1243.

Hubbard, N.L., S.C. Huber, and D.M. Pharr. 1989. Sucrose phosphate synthase and acid invertase as determinants of sucrose concentration in developing muskmelon (Cucumis melo L.) fruits. Plant Physiol. 91:1527-1534.

Hubbard, N.L., S.C. Huber, and D.M. Pharr. 1991. Sucrose phosphate synthase and other sucrose metabolizing enzymes in fruits of various species. Physiol. Plant. 82:191-196.

Husain, S.E., C. James, R. Shields, and C.H. Foyer. 2001. Manipulation of fruit sugar composition but not content in Lycopersicon esculentum fruit by introgression of an acid invertase gene from Lycopersicon pimpinellifolium. New Phytol. 150:65-72.

Ikoma, Y., M. Yano, and K. Ogawa. 1995. Cloning and expression of gene encoding ACC synthase in kiwifruit. Acta Hort. 398:179-186.

Isla, M.I., M.A. Vattuone, and A.R. Sampietro. 1991. Modulation of potato invertase activity by fructose. Phytochemistry 30:423-426.

Iwatsubo, T., H. Nakagawa, N. Ogura, T. Hirabayashi, and T. Sato. 1992. Acid invertase of melon fruits: Immunochemical detection of acid invertases. Plant Cell Physiol. 33:1127-1133.

Karuppiah, N., B. Vadlamudi, and P.B. Kaufman. 1989. Purification and characterization of soluble (cytosolic) and bound (cell wall) isoforms of invertase in barley (Hordeum vulgare) elongation stem tissue. Plant Physiol. 91:993-998.

Kim, J.Y., A. Mahé, S. Guy, J. Brangeon, O. Roche, P.S. Chourey, and J.L. Prioul. 2000. Characterization of two members of the maize gene family, incw3 and incw4, encoding cell-wall invertases. Gene 245: 89-102.

Klann, E.M., R.T. Chetlelat, and A.B. Bennett. 1993. Expression of acid invertase gene controls sugar composition in tomato (Lycopersicon esculentum) fruit. Plant Physiol. 103:863-870.

Klann, E.M., B. Hall, and A. B. Bennett. 1996. Antisense acid invertase (TIV1) gene alters soluble sugar composition and size in transgenic tomato fruit. Plant Physiol 112:1321-1330.

Koch, K.E. 1996. Carbohydrate-modulated gene expression in plants. Annu. Rev. Plant Physiol. Plant Mol. Biol. 47:509-540.

Lauriare, C., M. Lauriare, A. Strum, L. Faye, and M.J. Chrispeels. 1988. Characterization of $\beta$-fructosidase, an extracellular glycoprotein of carrot cells. Biochemie 70:1483-1491.

Lopez, M.E., M.A. Vattuone, and A.R. Sampietro. 1988. Partial purification and properties of invertase from Carica papaya fruits. Biochemistry. 27:3077-3081.

Lopez-Gomez, R. and M.A. Gomez-Lim. 1992. A method for extracting intact RNA from fruit rich in polysaccharides using ripe mango mesocarp. HortScience 27:440-442.

Lorenz, K., S. Lienhard, and A. Sturm. 1995. Structural organization and differential expression of carrot $\beta$-fructofuranosidase genes: Identification of a gene coding for a flower bud-specific isozyme. Plant Mol. Biol. 28:189-194.

Lowry, O.H., N.J. Rosenbrough, A.L. Farr, and R. Randall. 1951. Protein measurement with Folin-phenol reagent. J. Biol. Chem. 193: 265-275.

Ma, H., H.H. Albert, R. Paull, and P.H. Moore. 2000. Metabolic engineering of invertase activities in different subcellular compartments affects sucrose accumulation in sugarcane cells. Austral. J. Plant Physiol. 27:1021-1030.

Marchuk, D., M. Drumm, A. Saulino, and F.S. Collins. 1991. Construction of T-vectors, a rapid and general system for direct cloning of unmodi- 
fied PCR products. Nucl. Acids Res. 19:1154-1158.

Mercier, R.W. and J.P. Gogarten. 1995. A second cell wall acid invertase gene in Arabidopsis thaliana. Plant Physiol. 107:659-660.

Morris, D.A. 1982. Hormonal regulation of sink invertase activity: implications for the control of assimilate partitioning, p. 659-668. In: P.F. Wareing (ed.). Plant growth substrates. Academic Press, London.

Nguyen-Quoc, B. and C.H. Foyer. 2001. A role for 'futile cycle' involving invertase and sucrose synthase in sucrose metabolism of tomato fruit. J. Expt. Bot. 52:881-889.

Neubohn, B., S. Gubatz, U. Wobus, and H. Weber. 2000. Sugar levels altered by ectopic expression of a yeast-derived invertase affect cellular differentiation of developing cotyledons of Vicia narbonensis $\mathrm{L}$. Planta 211:325-334.

N'tchobo, H., N. Dali, B. Nguyen-Quoc, C. H. Foyer, and S. Yelle. 1999. Starch synthesis in tomato remains constant throughout fruit development and is dependent on sucrose supply and sucrose synthetase activity. J. Expt. Bot. 50:1457-1463.

Paull, R. E., W. Nishijima, M. Reyes, and C. Cavaletto. 1997. A review of postharvest handling and losses during marketing of papaya (Carica papaya L). Postharvest Biol. Technol. 11:165-179.

Pérez, J.A., J. Rodriguez, T. Ruiz, and L. Rodriguez. 2001. Expression of Pichia anomala INV1 gene in Saccharomyces cerevisiae results in two different active forms of hypoglycosylated invertase. Arch. Micro. 175:189-197.

Roitsch, T., M. Bittner, and D.E. Godt. 1995. Induction of apoplastic invertase of Chenopodium rubrum by D-glucose and a glucose analog and tissue-specific expression suggest a role in sink-source regulation. Plant Physiol. 108:285-294.

Ruan, Y.L. and J.W. Patrick. 1995. The cellular pathway of post-phloem sugar transport in developing tomato fruit. Planta 196:434-444.

Sambrook, J., E.T. Fritsch, and T. Maniatis. 1989. Molecular cloning: A laboratory manual. Cold Spring Harbor Laboratory Press, Plainview, New York.

Selvaraj, Y., D.K. Pal, M.D. Subrmaanyam, and C.P.A. Lyer. 1982. Changes in the chemical composition of four cultivars of papaya (Carica papaya L.) during growth and developmet. J. Hort. Sci. 57: 135-143.

Shizuya, H., B. Birren, U-J. Kim, V. Mancino, T. Slepak, Y. Tachiiri, and M. Simon. 1992. Cloning and stable maintenance of 300-kilobase-pair fragments of human DNA in Escherichia coli using an F-factor-based vector. Proc. Natl. Acad. Sci. USA 89:8794-8797.

Sonnewald, U., M.R. Hajirezaei, J. Kossmann, A. Heyer, R.N. Trethewey, and L. Willmitzer. 1997. Increased potato tuber size resulting from apoplastic expression of a yeast invertase. Nature Biotechnol. 15:794-797.

Sturm, A. 1996. Molecular characterization and functional analysis of sucrose-cleaving enzymes in carrot (Daucus carota L.). J. Expt. Bot. 47:1187-1192.

Sturm, A. 1999. Invertases. Primary structures, functions, and roles in plant development and sucrose partitioning. Plant Physiol. 121:1-7.

Sturm, A. and M.J. Chrispeels. 1990. cDNA cloning of carrot extracellular $\beta$-fructosidase and its expression in response to wounding and bacterial infection. Plant Cell 2:1107-1119.

Tang, G.Q., M. Luscher, and A. Sturm. 1999. Antisense repression of vacuolar and cell wall invertase in transgenic carrot alters early plant development and sucrose partitioning. Plant Cell 11:177-190.

Unger, C., J. Hofsteenge, and A. Strum. 1992. Purification and characterization of a soluble $\beta$-fructofuranosidase from Daucus carota. Eur. J. Biochem. 204:915-921.

Unger, C., M. Hardegger, S. Lienhard, and A. Sturm. 1994. cDNAcloning of carrot (Daucus carota) soluble acid $\beta$-frucofuranosidases and comparison with the cell wall isoenzyme. Plant Physiol. 104:1351-1357.

Weil, M., S. Krausgrill, A. Schuster, and T. Rausch. 1994. A 17 kDa Nicotiana tabacum cell-wall peptide acts as an in vitro inhibitor of the cell-wall isoform of acid invertase. Planta 193:438-445.

Yelle, S., R.T. Chetelat, M. Dorais, J.W. DeVerna, and A.B. Bennett. 1991. Sink metabolism in tomato fruit. Plant Physiol. 95:1026-1035.

Zhang, H.B., X. Zhao, X. Ding, A.H. Paterson, and R.A. Wing. 1995 Preparation of megabase-size DNA from plant nuclei. Plant J. 7: $175-184$.

Zhou, D., A. Mattoo, N. Li, H. Imaseki, and T. Solomos. 1994. Complete nucleotide sequence of potato tuber acid invertase cDNA. Plant Physiol. 106:397-398.

Zhou, L. and R.E. Paull. 2001. Sucrose metabolism during papaya (Carica papaya L.) fruit growth and ripening. J. Amer. Soc. Hort. Sci. 126:351-357.

Zhou, L., D.A. Christopher, and R.E. Paull. 2000. Defoliation and fruit removal effects on papaya fruit production, sugar accumulation, and sucrose metabolism. J. Amer. Soc. Hort. Sci. 205:644-652. 